\title{
Н.В. Вергельська
}

\section{ГЕОДИНАМІЧНІ АСПЕКТИ ВУГІЛЬНО-ВУГЛЕВОДНЕВИХ ФОРМАЦІЙ}

Осадконакопичення лише опосередковано пов'язане 3 геодинамічними процесами, які генеруються латеральною взаємодією плит літосфрери і їхнім переміщенням, а методи осадової геології об'єктивно тяжіють до уявлень про першочерговість вертикальної компоненти тектонічних рухів. Актуальність особливих зусиль щодо розв'язання проблеми вугільно-вуглеводневих формацій зумовлена низкою причин. По-перше, найвиразніша саме у вченні про вугленосні формації та їхній зв'язок з геосинклінальною основою вже порушує відношення з іншими розділами геології, які швидко модернізуються, та гальмує подальший розвиток теорії вуглегазоутворення як частини єдиного процесу еволюції франерозойської літосфрери. По-друге, промислове значення вугільно-вуглеводневих фрормацій, з якими пов'язані ресурси природного енергоносія, цінної технологічної сировини, а також комплекс супутніх вугіллю й вуглеводням металевих і нерудних корисних копалин, потребує якнайшвидшого залучення геодинамічного аналізу до вирішення практичних завдань вугільної геології. На основі мобілістської теорії - тектоніки плит - розглянуто можливі реконструкції та за допомогою них упорядковано просторове положення синхронних геологічних комплексів, які формувалися в типових геодинамічних обстановках, закономірно пов'язаних один з одним у системі давніх плит. У поєднанні інтерпретацій вертикальних формаційних рядів окремих геоструктурних зон з позицій геосинклінальноорогенічного циклу й перехід до переважного латерального геологічних комплексів, розвинених на великих територіях, і полягає особливість геодинамічного аспекту вугільно-вуглеводневих формацій.

Ключові слова: геодинаміка, вугільні басейни, вугільно-вуглеводневі формації, тектоніка, накопичення органогенної речовини.

Вступ. Осадконакопичення лише опосередковано пов'язане з геодинамічними процесами, які генеруються латеральною взаємодією плит літоссрери та їхнім переміщенням, а методи осадової геології об'єктивно тяжіють до уявлень про першочерговість вертикальної компоненти тектонічних рухів. Тому залучення осадових фрормацій у сферу геодинамічних досліджень $є$ досить складною проблемою, розв'язання якої можливе через адаптацію науково-методичної бази осадової геології й мінералогенії до теорії тектоніки плит.

Актуальність особливих зусиль щодо вирішення проблеми вугільно-вуглеводневих фрормацій зумовлена низкою причин. По-перше, найвиразніша саме у вченні про вугленосні формації та їхній зв'язок з геосинклінальною основою вже порушує відношення з іншими розділами геології, які швидко модернізуються, та гальмує подальший розвиток теорії вуглегазоутворення як частини єдиного процесу еволюції літосфери фанерозою. По-друге, промислове значення вугільно-вуглеводневих фрормацій, 3 якими пов'язані ресурси природних енергоносіїв, цінної технологічної сировини, а також комплекс супутніх вугіллю і вуглеводням металевих і нерудних корисних копалин, потребує якнайшвидшого залучення геодинамічного аналізу до вирішення практичних завдань вугільної геології. Брак спеціальних досліджень з типології вуглегазоносних (вугленосних) комплексів, накопичених і перетворених у різних геодинамічних обстановках, ускладнює їхнє повне застосування для регіональних палеогеодинамічних реконструкцій.

Вагомий доробок у вивченні вугільних і вугільно-вуглеводневих формацій належить А.Я. Радзівіллу, В.Ф. Шульзі, І.О. Майдановичу, М.М. Тетяєву, В.В. Білоусову, Г.О. Іванову, Ю.А. Жемчужнікову, Л.І. Пімоненко, В.В. Лукінову, О.С. Тараканову, О.І. Єгорову, І.Е. Вальц та багатьом іншим, дослідження яких ґрунтувалися на передових напрямах науки і дають можливість багатогранної оцінки вуглегазових покладів.

Використання традиційних моделей геосинклінально-орогенічного циклу не дало змоги пояснити багато особливостей будови, зональності й просторового розміщення вугільно-вуглеводневих (вугленосних) фрормацій у геологічних структурах світу та України зокрема. Геодинамічний підхід у низці випадків мав очевидний ефект, але для його повно(с) Н.В. Вергельська, 2018 
цінного втілення потрібно розробити відповідну класифікаційно-діагностичну систему, що дасть змогу внести вугільно-вуглеводневі формації до загальної системи різних геологічних об'єктів, які описуються єдиними законами розвитку літосфери. Це зумовило потребу досліджень досить широкого кола питань загальнотеоретичного й позарегіонального плану вугільно-вуглеводневих формацій.

Mema і завдання досліджень. Метою досліджень стало наукове обґрунтування принципів і методів геодинамічного аналізу вугільно-вуглеводневих формацій, а також його практичне застосування для підвищення ефективності прогнозування газоносності вугільних родовищ у межах України й суміжних держав; комплексування теоретико-методологічних розробок і конкретних прийомів вирішення наукових і прикладних завдань вугільної геології, що ґрунтується на уявленнях про геодинамічні обстановки вугільновуглеводневих формацій.

Виклад основного матеріалу. Історичний огляд розвитку досліджень вугільних (вугільно-вуглеводневих) фрормацій

В основі вчення про вугільно-вуглеводневі формації лежить система базових понять і уявлень вугільної геотектоніки, вивчення особливостей накопичення, перетворення й локалізації вуглегазоносних комплексів у земній корі у зв'язку з єдиними законами розвитку та принципами структурування геологічного простору. Вугільна геотектоніка систематизує відомості про мінливість вуглегазоносних комплексів завдяки розробленню загальних і регіональних класифікаційно-діагностичних систем, побудованих на тектоногенетичних принципах, вивчає закономірності вуглегазоутворення як частини єдиного геолого-історичного процесу, розробляє моделі розвитку й трансформації вуглевміщувальних структур і алгоритми прогнозування вуглегазових (вугільних) родовищ. Не менш важливе забезпечення постійного взаємозбагачення зв'язку вчення про вуглегазоносні формації з іншими сучасними напрямами геологічних досліджень, зокрема й газоносністю вуглепородних масивів.

Геотектонічний аспект

3 виникненням у середині XVIII століття гіпотези про автохтонний (болотний) генезис вугілля з торфу, перетвореного в надрах Землі, у геологів з'явилася можливість за наявністю й характером вугленосних товщ оцінювати особливості давніх, вертикальних переміщень гірських мас. Пізніше, з розвитком уявлень про широтну й кліматичну зональності, закономірності розміщення вугленосних (вуглегазоносних) басейнів на континентах досліджували для наукового обґрунтування горизонтальних рухів великих корових елементів. Унаслідок автохтонної моделі вуглеутворення як процесу періодичного виходу седиментаційної поверхні з-під вод басейну обов'язково потрібна повна компенсація тектонічних занурень з приростом потужності накопичених осадів. Водночас добре визначена у вугленосних відкладеннях повторюваність (циклічність) фаціальних умов седиментації дала змогу відкрити перспективи вивчення проблеми геотектонічного контролю паралічного й лімнічного осадконакопичення $[89,163,197]$. Ранній період розвитку вугільної геотектоніки, який тривав до кінця 20-х років XX століття, характеризувався пануванням досліджень ландшафтних класифікаційно-діагностичних систем, а також систем, в яких роль геотектонічного чинника не була пріоритетною. Ситуація принципово змінилася 3 виникненням глобальної геотектонічної концепції геосинкліналей і платформ, що стала потужним засобом впливу на весь процес розвитку геологічної науки першої половини XX століття. Для вугільної геотектоніки велике значення мало опублікування статті Г. Штілле (1926р.) зі знаменною назвою «Вугленакопичення як геотектонічна проблема». Ї̈̈ вихід у світ визначає початок класичного етапу розвитку вугільної геотектоніки. Г. Штілле вперше обґрунтував найтісніший зв'язок більшості характеристик вугленосних комплексів з відмінностями в ступені рухливості платформного й геосинклінального етапів розвитку вуглевміщувальних прогинів, запропонувавши як головний тектоногенетичний принцип побудови класифрікаційно-діагностичних систем вугільних басейнів. Найповнішого розвитку геосинклінальна вугільна геотектоніка отримала в працях Г.О. Іванова. На теоретичній 
основі геосинклінальної концепції (суто вертикальний варіант), як і М.М. Тетяєва - В.В. Білоусова, Г.О. Іванов розробив першу загальну класифікаційно-діагностичну систему вугленосних формацій за тектоногенетичними принципами, коливально-хвильову модель розвитку вугленосних осадових басейнів. Усі син- та епігенетичні особливості вугленосних відкладів Г.О. Іванов пов'язував з глибинами первинного занурення вуглевміщувальних прогинів. Крім геосинклінальних (глибоких прогинів) і платформної (дрібних прогинів), він виділив групу проміжних або перехідних формацій, що не мають чітких ознак полярних таксонів і тяжіють до середніх за глибиною прогинів.

Геоструктурна школа будувала класифрікаційно-діагностичні системи для положення вугільних басейнів у сучасних структурах земної кори, зберігши терміни геосинкліналь і платформа тільки для позначення латеральної неоднорідності [6, 9].

Прихильники геоструктурно-стадійного напряму намагалися вирішити проблему класифікації перехідної групи на основі уявлень про закономірності тимчасових циклів розвитку тектонічних процесів [2, 3].

У геологічній науці почався процес деструкції класичної форми геосинклінальної концепції через ії доповнення різними, але пов'язаними з поняттям про геосинкліналі геотектонічними побудовами.

Використання групи активізаційних гіпотез, а також ідей про самостійність орогенного режиму й протиставлення природи протоорогенезу і дейтероорогенезу (М.С. Нагібіна, Ю.М. Пущаровський, О.Д. Щеглов, Л.І. Красний, К.В. Боголепов та ін.) наприкінці 70-х років дало змогу М.В. Іванову, О.Г. Портнову, О.О. Тимофєєву, В.Ф. Череповському розпочати модернізацію класичної системи вугільної геотектоніки, відкривши новий етап її розвитку $[6,9,10]$.

Унаслідок цього були виявлені важливі особливості розміщення і складу вугленосних формацій в гірськоскладчастих областях, запропоновані різні орогенні класифікаційнодіагностичні системи. Водночас в них були збережені базові уявлення про однакову циклічність геотектонічних режимів розвитку територій. Цикл Штілле був побудований якоюсь епікратонною стадією (активізації дейтероорогенезу) або замість платформного режиму після орогенного в ньому виділявся параплатформний (склепінно-бриловий) етап. Відповідно виділялись різні групи і типи вугленосних формацій.

Аспект тектоніки плит

Основна привабливість ідей тектоніки плит як найбільш розробленої концепції сучасного мобілізму має дуже широкі інтерпретаційні можливості і високий ступінь синтезу й аналізу найрізноманітніших природних явищ, виведених 3 базових моделей переміщення і взаємодії глибинних структур літосфери. Використання цієї теорії дає змогу під суттєво новим поглядом розглянути комплекс різноманітних геологічних процесів і чинників вуглегазоутворення (вуглеутворення).

У геології регіональні дослідження на основі теорії тектоніки плит прийнято називати геодинамічними. Самостійну гілку геодинамічних досліджень, що зумовлює седиментологічне обґрунтування базових моделей тектоніки плит, С.І. Романовський запропонував називати літогеодинамікою [10]. Особливістю літогеодинаміки стають дедалі різноманітніші завдання, зокрема й розроблення наукової системи вугільної геодинаміки. Така ситуація потребує проведення досить складних додаткових досліджень, що стосуються особливостей будови й мінералогенії седиментогенезу вугільновуглеводневих об'єктів, які формувалися в різних геодинамічних умовах. Попри лідерство зарубіжної геології в розвитку теорії тектоніки плит, великих досліджень, які спеціально стосуються геодинамічних аспектів вуглеутворення, в її межах не виконано. Винятком $€$ монографрія П. Роберта (1987), присвячена особливостям зміни органічної, зокрема вугільної речовини, у геодинамічно різнотипових осадових басейнах.

На початку 80-х років опубліковані праці $[3,6,7]$, що розглядають вуглеутворення 3 позицій тектоніки плит. Виникнення й розвиток геодинамічного підходу до формаційного аналізу вугільно-вуглеводневих (вуглегазоносних) фрормацій треба розглядати як закономірний етап оновлення теоретико-методологічних основ вугільної геології задля 
їхнього чергового узгодження із сучасною геотектонічною наукою. Для проведення глобальних палеогеодинамічних реконструкцій сьогоднішній рівень вивченості вугільновуглеводневих формацій достатній, але результати аналізу закономірностей вуглеутворення тільки у зв'язку з переміщенням плит поверхнею геоїда ймовірно відрізнятимуться від тих, що колись отримали ще А. Вегенер (1913) і А. Дютойт (1930). Найцікавішим $€$ використання потенціалу тектоніки плит для розшифрування давніх геодинамічних ситуацій вуглегазоутворення кожної епохи накопичення органогенної речовини.

Геодинамічна обстановка вуглегазоутворення (вуглеутворення) - це характерний комплекс корових і поверхневих умов процесу, пов'язаний 3 положенням осадового басейну (вугільно-вуглеводневих формацій) за відношенням до кордонів плит і активними внутрішньоплитовими зонами. Геодинамічна обстановка визначає головні особливості формування або трансформування осадових басейнів, їхнє положення в ряді синхронності геологічних формацій вугільно-вуглеводневих басейнів. Розрізняються обстановки вуглеторфоносних седиментацій і обстановки їхнього перетворення. Зміна їх у часі зумовлюється зміною позиції осадового басейну в межах кордонів плит і може розглядатися як процес, що має обмежене число можливих реалізацій - типових геодинамічних ситуацій. Такий підхід дає змогу розглядати розвиток вуглегазоносного басейну як дискретний перехід з однієї типової геодинамічної обстановки в іншу 3 послідовним набуттям нових і втратою частини колишніх властивостей структури й речовини. Оскільки найважливіші властивості вугільно-вуглеводневих формацій закладаються на стадії седиментації, головне значення в усіх реконструктивногенетичних, типологічних і прогнозних побудовах має геодинамічний тип органогенного (вугільно-вуглеводневого) осадового басейну.

Фактичною базою геодинамічного аналізу вугільно-вуглеводневих фрормацій стають не тільки вони самі, а й увесь їхній вміщувальний структурно-формаційний одновіковий ансамбль, в якому методами регіональних палеогеодинамічних реконструкцій відновлюються синхронні (латеральні) ряди, що відповідають колишнім геодинамічним ситуаціям. Аналіз змін вугільно-вуглеводневих формацій набуває водночас комплексного багатофакторного характеру. Ландшафтно-палеогеографічний, тектонічний, а багато в чому й кліматичний складники загальних умов торфонакопичення й вуглегазоутворення виступають тут як частини єдиного цілого - геодинамічної обстановки. Тому тектоногенетичний принцип у геодинамічних класифікаційно-діагностичних системах може бути реалізований з більшою повнотою, порівнюючи з геосинклінальним або іншими вертикально-циклічними [9].

Аналіз передбачає з'ясування специфіки вуглегазоносних комплексів, сформованих у типових геодинамічних обстановках, і розроблення на цій основі відповідної класифрікаційно-діагностичної системи, яка виконує функції, традиційно властиві вугільній геотектоніці. Найважливішим прийомом загального (регіонального) геодинамічного аналізу $\epsilon$ палеогеодинамічні реконструкції, націлені на розпізнання серед давніх геологічних утворень аналогів сучасних геодинамічних ситуацій, зокрема й торфонакопичення. Для цього вивчають породно-структурні комплекси - індикатори, склад і просторово-вікові співвідношення яких можуть бути розшифровані за допомогою теоретичних моделей тектоніки плит. Відповідно до цієї теорії, зміни в параметрах геодинамічного процесу в одному із сегментів плит літосфери зумовлюють адекватну й передбачувану реакцію ії частин, суміжних плит і в підсумку позначаються на поведінці всього їхнього ансамблю. Взаємозалежна поведінка плит визначила закономірну картину просторового розміщення синхронних типових геодинамічних ситуацій і відповідно склад, будову й взаємну орієнтацію латеральних рядів, що формувалися в одновікових геологічних комплексах, в яких вугільно-вуглеводневі формації мали строго певне положення. Розшифровуючи будову й геодинамічну природу латеральних структурнофрормаційних рядів, розвинених на досліджуваній території, можна визначити геодинамічні 
обстановки фрормування кожного вугільного басейну або його окремої частини в певний період часу та посторормаційні зміни.

Апріорі визначення позиції досліджуваного об'єкта в геодинамічній моделі структури вищого порядку (наприклад, вугільно-вуглеводневого басейну в моделі складчастої області) дає змогу зробити досить достовірне прогнозування його ймовірних характеристик, якщо є відповідна класифрікаційно-діагностична система таких об'єктів.

Побудова класифікаційно-діагностичної системи можлива в разі взаємодоповнювального використання трьох методичних підходів [198]:

1) вивчення особливостей дійсних вугільно-вуглеводневих фрормацій, геодинамічна позиція яких установлена регіональними палеогеодинамічними реконструкціями;

2) моделювання процесів накопичення й перетворення у вугільно-вуглеводневих формаціях у різних режимах вертикальної і горизонтальної рухливості літосфери;

3) ретроспективної екстраполяції даних про геодинамічні ситуації сучасного торфонакопичення.

Накопичення й перетворення органогенної речовини

Вуглеторфоносна седиментація являє собою процес дискретного накопичення торфу на заболоченій субаеральній поверхні осадового басейну. Окремі фази цього процесу циклічно чергуються із субаквальним накопиченням переважно теригенного матеріалу. Характер циклічної будови комплексів, в яких накопичуються й формуються вугільновуглеводневі формації осадового басейну, виводиться з режиму вертикальних тектонічних рухів субстрату, що також зумовлений типом геодинамічної обстановки седиментації. У зв'язку із цим кількісні параметри вуглегазоносних відкладів (у разі обліку специфічних аспектів формування торфогазоносних покладів), а також геотермальний метаморфізм вугільної речовини зумовлюються інтенсивністю й характером територіального розподілу теплових палеопотоків, геотермічними градієнтами, а також можливими глибинами занурення вугільних пластів у різних зонах осадових палеобасейнів. 3 первинним типом геодинамічної обстановки пов'язується, у деяких випадках, контактова зміна вугілля. Усі епігенетичні зміни: складчастість, частково контактовий метаморфізм вугілля, фрагментація і руйнування вуглегазоносних комплексів розглядаються тільки як результат зміни геодинамічних обстановок вуглегазоутворення, характерних тільки для окремих регіонів.

Вугільні пласти змінені в надрах - це викопні палеоторф'яники, виникнення, розвиток, руйнування й поховання яких в осадових басейнах хоч і контролювалося чинниками зовнішнього середовища, але насамперед відбувалося за своїми власними законами, властивими високоорганізованій живій матерії під час взаємодії з глибинними процесами, зокрема й фрлюїдними еманаціями [1]. Принципово відмінний від сталих тектоноседиментаційних систем спосіб концентрації вихідного фрітогенного (рослинного) матеріалу вугільно-вуглеводневих формацій потребує уточнення використання повної компенсаційної моделі торфонакопичення й вуглеутворення [6, 7].

На матеріалах сучасного вивчення болотних комплексів і розшифрування в будові рослинного складу вугільних пластів потрібно провести адаптацію палеоторфовищ до мінливих умов водного режиму середовища накопичення та захоронення. Однією 3 основних умов безперервного накопичення торфу в болотному масиві $\epsilon$ підтримання рівня вод поблизу поверхні дедалі більшого торфовища. Головним чинником, що контролює поведінку цього рівня, можна визнати режим вертикальних тектонічних рухів. Однак допустимі межі коливань рівня вод, що рівнозначно діапазону амплітуд і швидкостей тектонічних рухів, не настільки вузькі, як цього потребує вугільна седиментологія. Торфовища, особливо на зрілих стадіях розвитку з накопиченням запасів води й торфу набувають потужних механізмів саморегуляції водного режиму й усе успішніше можуть протистояти зовнішньому впливу, не припиняючи водночас концентрації біогенної маси, зокрема й унаслідок абіогенного (глибинного) підтікання.

Аналіз явища саморегуляції болотних екосистем засвідчує, що механізми фріксації зовнішніх, зокрема й тектонічних режимів у продуктах розвитку живих саморегулювальних

Тектоніка і стратиграфія, 2018, вип. 45 
систем, якими в минулому були палеоторфовища (сучасні вугільні пласти), суттєво відмінні від систем нерухомої природи.

Скориговані, усе ще поширені у вугільній геології уявлення про стабільність тектонічних обстановок накопичення органогенної речовини потужних вугільних пластів і відповідають критеріям їхнього прогнозування. 3 використанням методів математичного моделювання доведено, що оптимальним тектонічним режимом накопичення потужних палеоторфовищ був режим пульсувального занурення в стилі циклогенезу, який запропонував П. Прюво, що добре узгоджується з висновками Г.Ф. Крашеніннікова і О.О. Тимофрєєва з того ж питання. Підтверджено спостереженнями П.П. Тимофеєєва та Л.І. Боголюбової можливість палеореконструкції режимів тектонічних рухів 3 огляду на швидкості проходження торфом фрормувального горизонту покладів. 3'ясовано, що оптимальні геодинамічні обстановки формування потужних пластів вуглегазоносних (вугленосних) комплексів були пов'язані 3 розвитком внутрішньоконтинентальних рифттових зон [9].

Запропоновано оригінальну методику виявлення кількісної оцінки ступеня циклічності вуглегазоносних відкладень з використанням процедур факторного аналізу, що дає змогу виділити із загальної дисперсії (мінливості) розрізів ту ії частину, яка згідно з прийнятою моделлю процесу, може бути пов'язана з впливом конседиментаційних тектонічних рухів. Ці чинники можуть слугувати підставою для виділення однакових седиментаційних циклів і кореляції розрізів в умовах спрямованого фаціального аналізу на площі басейну [3, 10]. Побудовані теоретичні графіки такої залежності засвідчили хороший збіг з результатами емпіричних спостережень Г.О. Іванова, О.Б. Гуревіча, Г.П. Дубаря, М.В. Іванова, В.М. Сальнікова та інших геологів із цієї проблеми в Донецькому, Тунгуському, Печорському, Сахалінському вугільних басейнах $[3,6,10]$. Такі дослідження можуть бути використані під час реконструкції палеогеодинамічних режимів у вуглегазоносних осадових басейнах.

Стан сучасних торфогенних, потенційно вуглегазоносних осадових басейнів у системі взаємодії літосферних плит дає змогу побічно визначати геодинамічні режими в різні епохи накопичення органогенної речовини. У сучасних досліджених торфовищах у межах Українського щита й Дніпровсько-Донецької западини встановлені відмінності, що закладаються на торфогенній стадії і простежуються до стадії кам'яного вугілля: для зразків торфу із щита краще зберігаються структурні компоненти (телініти), а із западини більш подрібнені (атрити, колініти).

Структурно-тектонічні моделі формування вугільно-вуглеводневих фрормацій

Проблема аналізу великих поліформаційних вуглегазоносних басейнів, у складі яких можливі вертикальні (Дніпровсько-Донецька западина) і горизонтальні (Донецький басейн) реконструкції декількох різнотипових палеобасейнів, указує на сприятливий перервнонеперервний тектоноседиментаційний режим вуглегазоутворення в трансконтинентальних лінійних і ареальних зонах рифтогенезу, рифтоподібних типових прогинах орогенних активних околиць континентів і успадкованих епійрогенних западинах у межах акреаційноскладчастих областей.

3 позиції теорії мобілізму, рухливість і характер взаємодії літосфрерних плит виступають як інтегральний чинник вуглегазоутворення, що породжує типові геодинамічні обстановки - ландшафтно-структурно-тектонічні ситуації, в яких відбувався розвиток вуглегазоносних палеобасейнів [9].

Для накопичення торфовищ, що передували вуглегазоутворенню, потрібне було просторово-тимчасове суміщення чотирьох взаємопов'язаних умов: розвитку осадового басейну з компенсаційним тектоноседиментаційним режимом, його положення в межах гумідного або близького до нього за типом клімату, відповідного еволюційного рівня й таксономічного складу наземних рослин і фрлюїдо-динамічного режиму структури $[1,8,9]$. Такими нішами могли слугувати латералі пасивних континентальних околиць, затоки над рифтами - авлакогенами, що змінюються з просуванням углиб континентів, естуаріями річкових долин. Інтенсивний ранньодевонський рифтогенез на платформах Лавразійської групи до середини цього періоду забезпечив розвиток зазначених ландшафтно- 
геодинамічних ситуацій. У середині девонського періоду основні континентальні фррагменти кістяка території Східноєвропейської і Сибірської платформ, а також Казахстанський акреаційний масив у своєму русі на північ змістилися в гумідний екваторіальний пояс. Клімат став сприяти торфонакопиченню та вуглегазоутворенню [11]. Сукупність геодинамічних процесів, що проявилися в зміщенні континентальних мас в екваторіальну область Землі з їхньою одночасною крайовою деструкцією, у середині девонського періоду створили потрібні тектоноседиментаційні та кліматичні передумови для розвитку систем торфонакопичення (рис. 1).

Середньодевонські вугільні пласти складені кутикуловими (ліптобіолітовими) різновидами з прошарками і лінзами сапропелевих. Кардинальна зміна таксономічного складу рослинного покриву в пізньому девоні привела до виникнення вже більш розвинених екосистем торф'яних боліт і суттєво вплинула на режими поверхневого стоку, перенесення пластичного матеріалу й поховання біомаси. Переважно приморські торфонакопичувальні системи стали фіксувати вже широкий спектр рослинних фррагментів різного хімічного складу. Пізній девон, на який припадає поява першого гумусового вугілля, став часом початку стійкого, частково саморегулювального торфонакопичувального процесу. Потенціал палеофітних торфоутворювачів стримувався відсутністю великих седиментаційних басейнів, розвиток яких над рифтами почався тільки наприкінці раннього карбону (Люблінський і Львівсько-Волинський басейни, Переддобруджа, Західний Донбас і Донбас). До того ж великі простори материкової суші ще перебували в аридному тропічному поясі. Недостатньо виражена саморегуляційна здатність стародавніх болотних систем прив'язувала їх до порівняно вузького ареалу пасивно-окраїнних геодинамічних ситуацій (рис. 2).

Наприкінці девону тенденція до розсування й деструкції крайових частин континентів змінилася їхнім зближенням 3 формуванням конвергентних периконтинентальних i островодужних систем. Приблизно 340 млн років тому всі три материкові суші сучасної Євразії зблизилися. Відбулося майже повне закриття Уральського палеоокеану, різке скорочення Палеотетісу й Туркестанського океанічного басейну. Водночас у поведінці континентів спостерігалися істотні відмінності. Європа з високою швидкістю зміщалася на північ, а Сибір, повільно просуваючись у тому ж напрямку, головним чином відчував обертання за годинниковою стрілкою. Закриття океанів усунуло колишні фрітогеографічні бар'єри, що призвело до відомої швидкої агресії ангарської фолори Сибіру на територію Казахстану. 3 іншого боку, різні швидкості широтного переміщення континентів спричинювали відмінності в темпах еволюції Європейських і Ангарського рослинних угруповань [5].

Розвиток конвергентних геодинамічних ситуацій, а також нових типів уже орогенних осадових басейнів за часом збігаються з формуванням великих епірифтових прогинів, успадкованих у ранньодевонських дивергентних структур, а також надрифтових басейнів пізньорифейської ініціації. Ця вкрай важлива обставина зумовила виникнення в середньому-пізньому карбоні і пермському періоді численних великих, різноманітних у геодинамічному відношенні щодо вуглегазоносних осадових басейнів усіх трьох геодинамічних груп. Унікальне поєднання кліматичних і тектоноседиментаційних умов, генерованих рухливістю й характером взаємодії плит, і визначило виникнення пермкарбонового максимуму вуглегазоутворення (рис. 3). У цю епоху процес торфонакопичення не тільки тривав на пасивних континентальних околицях (ЛьвівськоВолинський і Люблінський басейни) і в епірифтових прогинах авлакогенів (Донбас), але й створював нові обстановки басейнів накладених западин акреційних областей (Кузбас, Мінусинський басейн), передорогенних прогинів (Рурський, Аппалачський та Печорський басейни) і надрифтових синекліз внутрішніх областей давніх платформ (Підмосковний басейн) $[6,9,10]$.

Наприкінці тріасу торфонакопичення відновилося на низці колишніх його площ вуглегазоносних басейнів (рис. 4). Уперше широкий розвиток отримали внутрішньоконтинентальні рифтогенні обстановки: за східним схилом Уралу, південно- 
східної Азії, Океанії та Австралії. Орогенні басейни стали виникати вздовж усього південно-східного краю континенту, який відчував зіткнення з малими континентальними масами. Поєднання рифтогенного й орогенного вуглеутворення привело до виникнення численних вугільно-вуглеводневих формацій ранньомезозойської епохи, що протягуються у вигляді планетарного поясу вуглеутворення від Англії до Аляски через Євразійський материк. Цей процес мав неабиякий розвиток на північному схилі Центрально-Азійського складчастого поясу. Зокрема, у зоні тилових розтягувань активної континентальної окраїни почалося формування великих вуглегазоносних басейнів. В успадкованих западинах епейрогенної групи відновилося накопичення, а в епейрогенних надрифтових басейнах девонських авлакогенів розпочали формуватися органогенні товщі. Отже, частина вуглегазоносних басейнів ранньомезозойського етапу мала «молоду» рифтову природу (східна частина Євразії), частина утворила епірифтові прогини над тріасовими структурами розтягування й тиловими рифтоподібними прогинами орогенного генезису, а частина заповнювала епейрогенні надрифтові депресії девонського закладання. У зв'язку зі збереженням основних ознак геодинамічних ситуацій до кінця юрського періоду пізньомезозойська епоха вуглегазоутворення плавно продовжила ранньомезозойську (рис. 5). Певною відмінністю пізньомезозойського вуглеутворення стало розширення його епірифтового типу, аж до фоомування вугле- та вуглегазоносного приморського й внутрішньоконтинентального накопичення в Сибіру та на сході континенту. Найактивніші геодинамічні процеси, що привели до утворення нових великих областей пізньомезозойської торфовугленосної седиментації, були зосереджені на Тихоокеанській околиці Євразії та почалися наприкінці середньоюрської епохи. До апту закінчилося об'єднання дрібних континентальних мас, які ссрормували складнопобудовані акреційні області, збільшивши північно-східний і східний край Євразії [4, 9,11].

Торфонакопичення, яке розвивалося в цьому регіоні з кінця юри до середини крейди локалізувалося в басейнах накладених і залишкових западин, у тилових і фронтальних прогинах острівнодугових систем. Закладення в середині крейдового періоду нової активної континентальної окраїни створює умови для вуглегазоутворення в поясі типових розтягувань, а також приводить до тектонічної релаксації й розвитку дивергентних зон 3 інтенсивним вуглегазонакопиченням уздовж перманентно активної зони, що поєднує Євроазійську і Північноамериканську мегаплити (рис. 6). У другій половині крейди околиці припинили вуглегазоутворення в материковій частині сходу Євразії і тільки з еоцену процеси торфонакопичення відновилися тут 3 новою силою. Кайнофрітні торфогенерувальні спільноти, які отримали ще більшу стійкість у зовнішньому середовищі, стали здатні до захоплення всієї нині відомої гами геодинамічних обстановок торфонакопичення й вуглегазоутворення. Кліматичні зміни стали більшою мірою визначатися особливостями циркуляції океанічних вод і атмосферних мас, які також залежали від відкриття й закриття проток, зростання i руйнування берегових i внутрішньоконтинентальних хребтів. На перше місце в утворенні кліматичних умов внутрішньо- і периконтинентальної торфовуглегазоносної седиментації вийшли малі взаємні переміщення материків, а не їхній дрейф поверхнею геоїда.

У палеоцені, олігоцені та міоцені торфонакопичення й вуглегазоутворення не отримало істотного поширення, створюючи локальні зони в межах фрормування вугільних басейнів у попередні епохи (рис. 7, 8). Найінтенсивнішою епохою вуглегазоутворення, що може порівнятися з попередніми, є еоценова. Збільшення продукції біомаси рослин і можливість ії консервації в осадових басейнах дає змогу формуванню нових вугільновуглеводневих формацій. Зіткнення в олігоцені Індії 3 Євразією активізувало тектоноседиментаційні процеси органогенного накопичення речовини. Вуглегазоносні басейни переважно орогенної групи були сфрормовані в Закавказькому, Карпатському й Північнокавказькому регіонах і на сході Євразії [4, 9].

Загалом геодинамічні обстановки кайнозойського торфонакопичення й вуглеутворення були дуже близькими до ситуацій сучасного торфонакопичення, що в 
деяких випадках (басейни Філіппін та Греції) безпосередньо триває на раніше освоєних площах розвитку депресійних структур і дотепер (рис. 9).

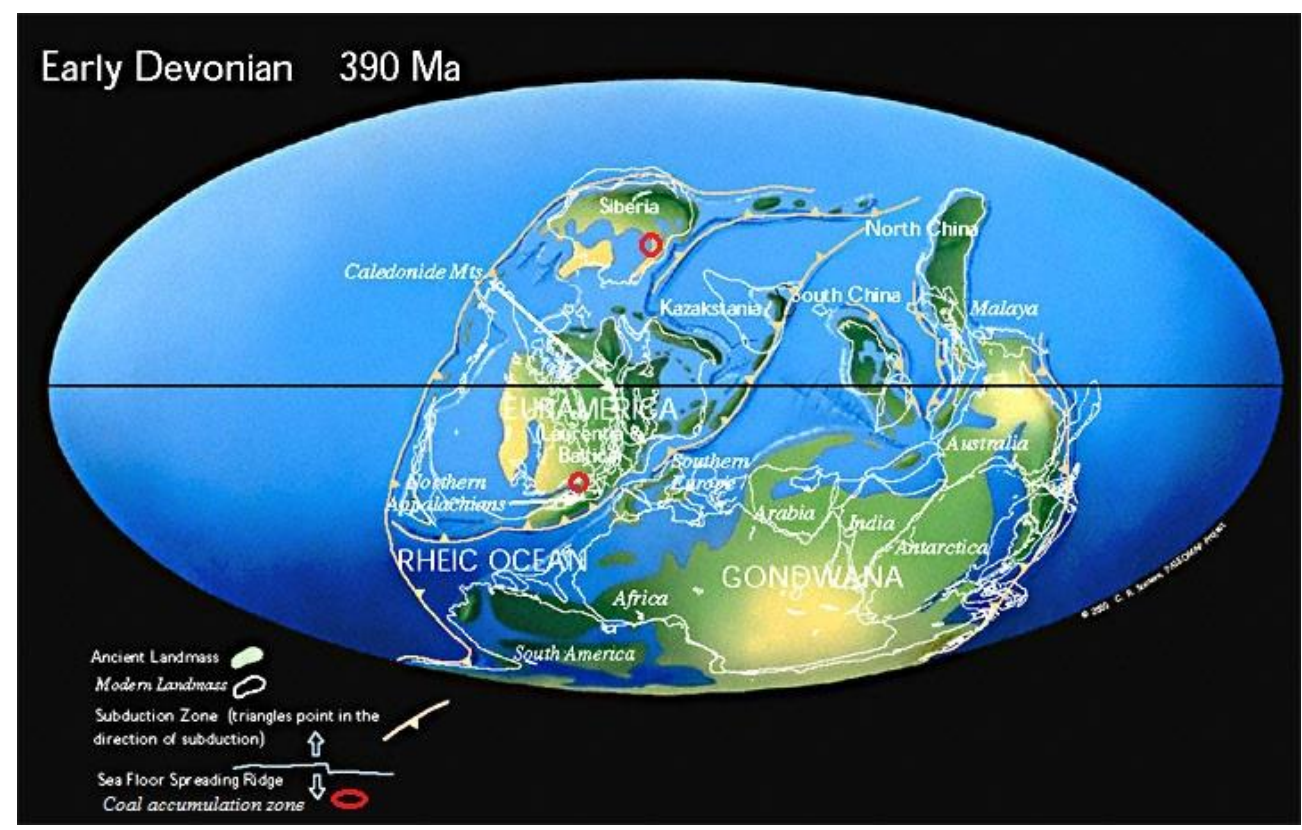

Рис. 1. Зони вугленакопичення в девоні. Виконав автор на основі Paleogeography, PALEOMAP $[12,13]$ Умовні позначення до рисунків $1-9$ :
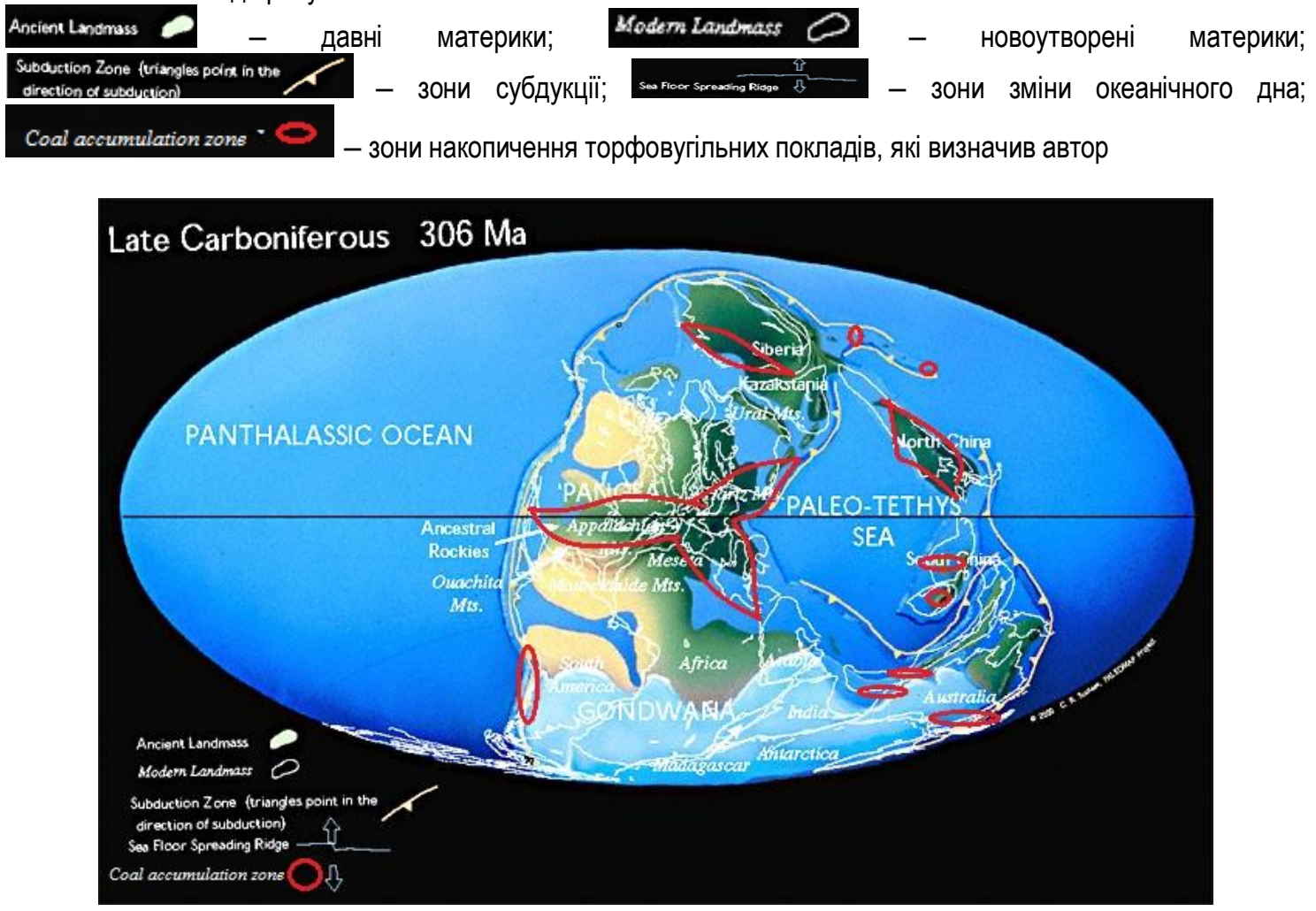

Рис. 2. Зони вугленакопичення в карбоні. Виконав автор на основі Paleogeography, PALEOMAP $[12,13]$ 


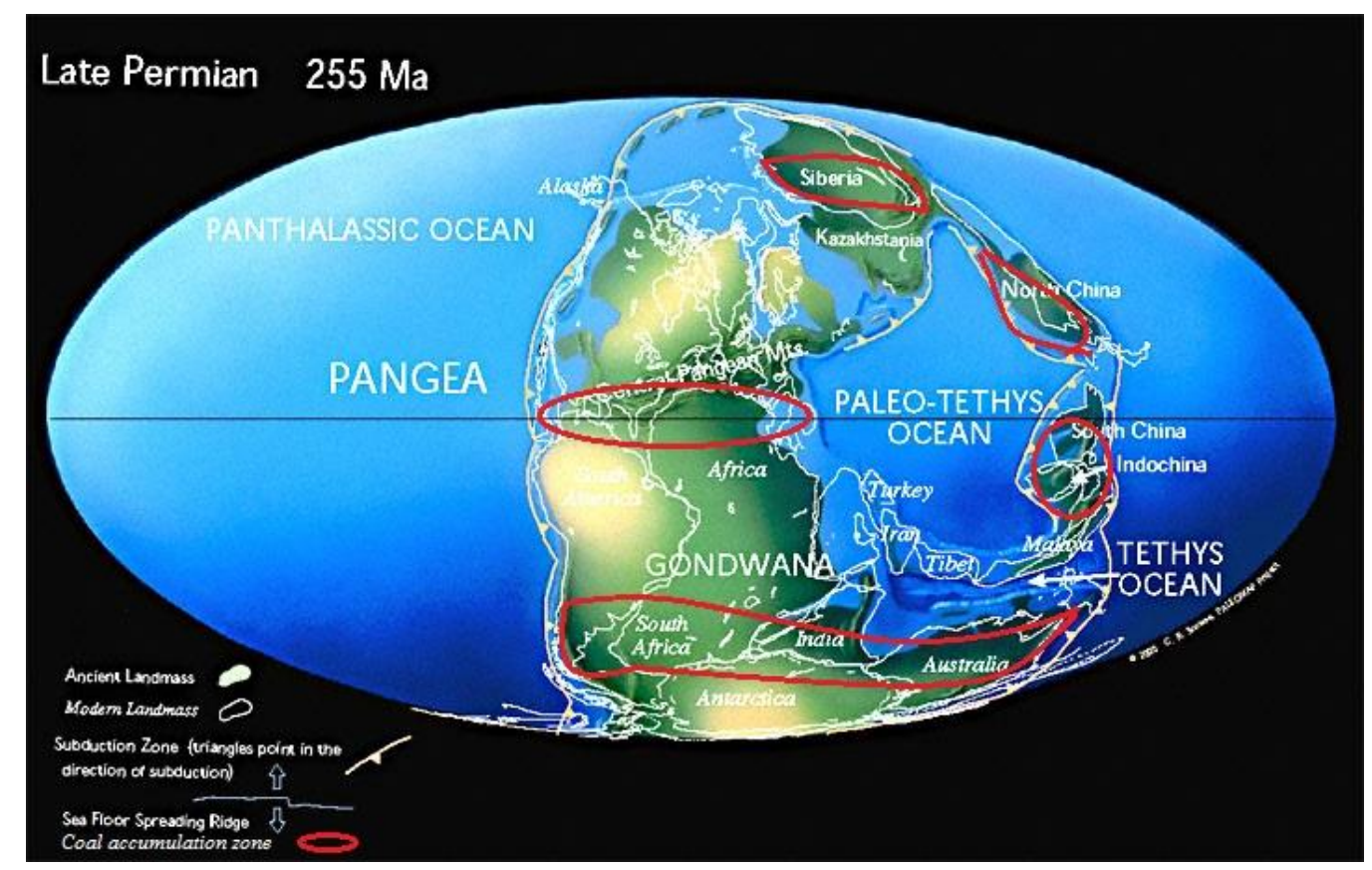

Рис. 3. Зони вугленакопичення в пермі. Виконав автор на основі Paleogeography, PALEOMAP [12, 13]

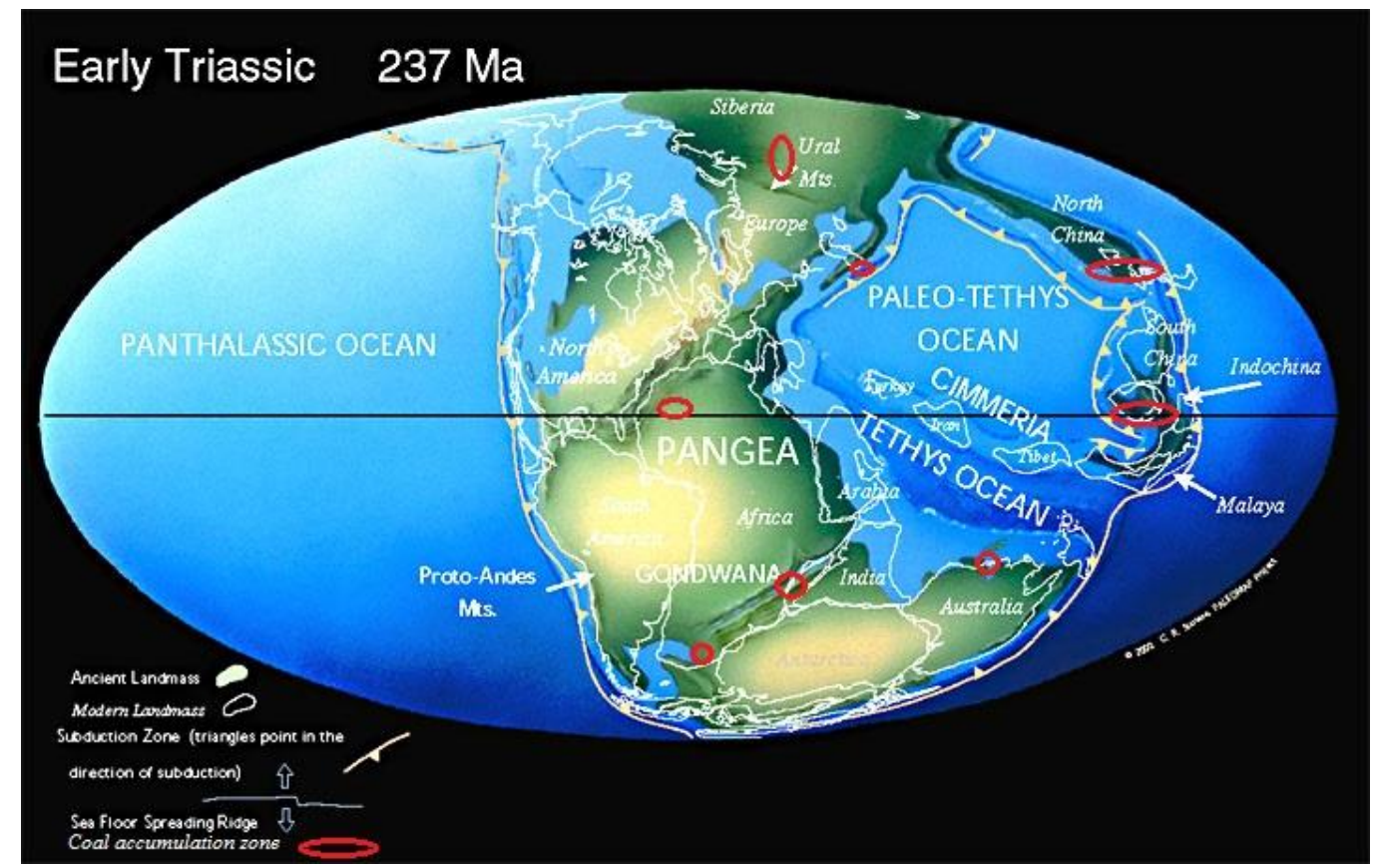

Рис. 4. Зони вугленакопичення в тріасі. Виконав автор на основі Paleogeography, PALEOMAP [12, 13] 


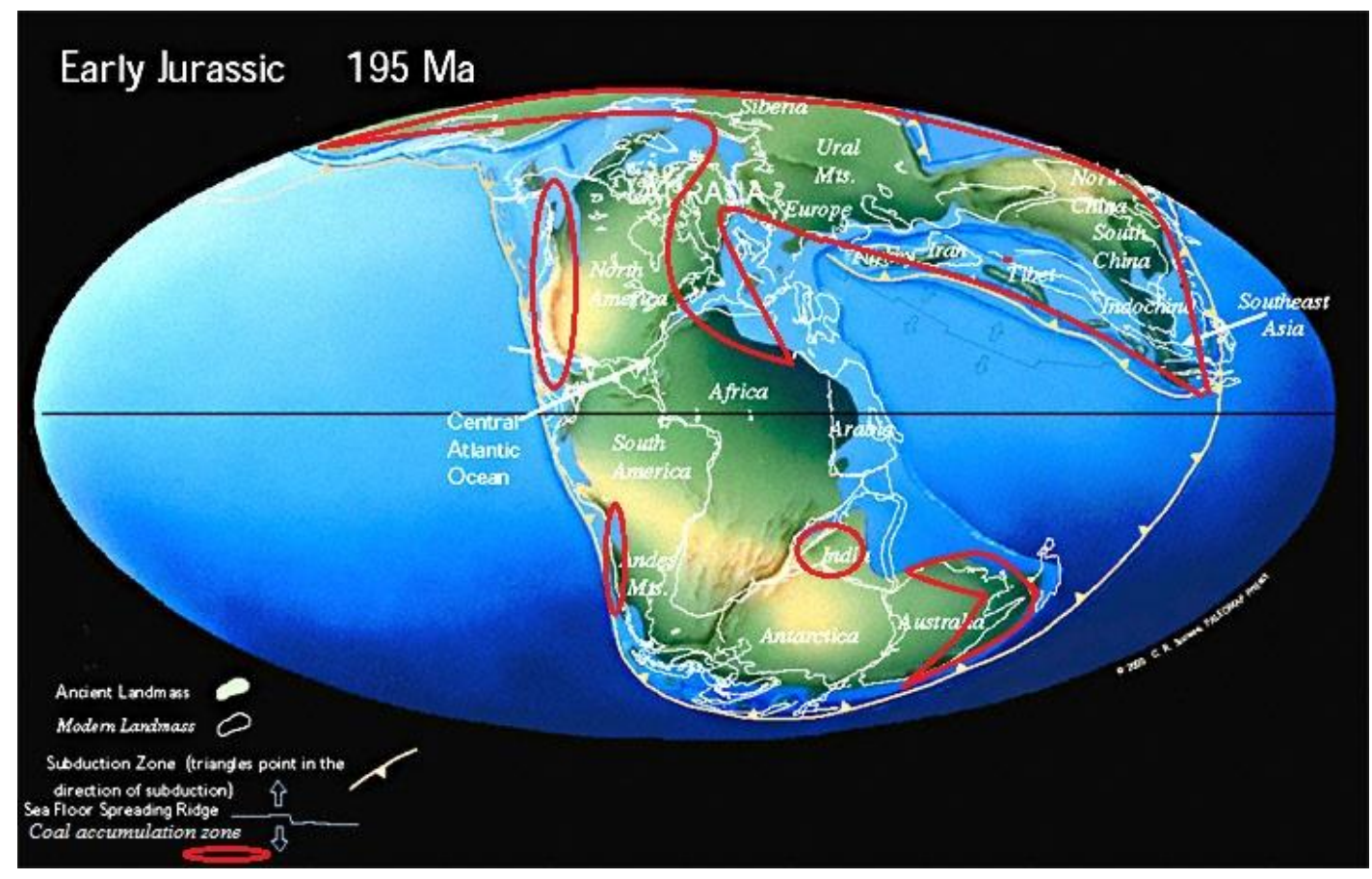

Рис. 5. Зони вугленакопичення в юрі. Виконав автор на основі Paleogeography, PALEOMAP [12, 13]

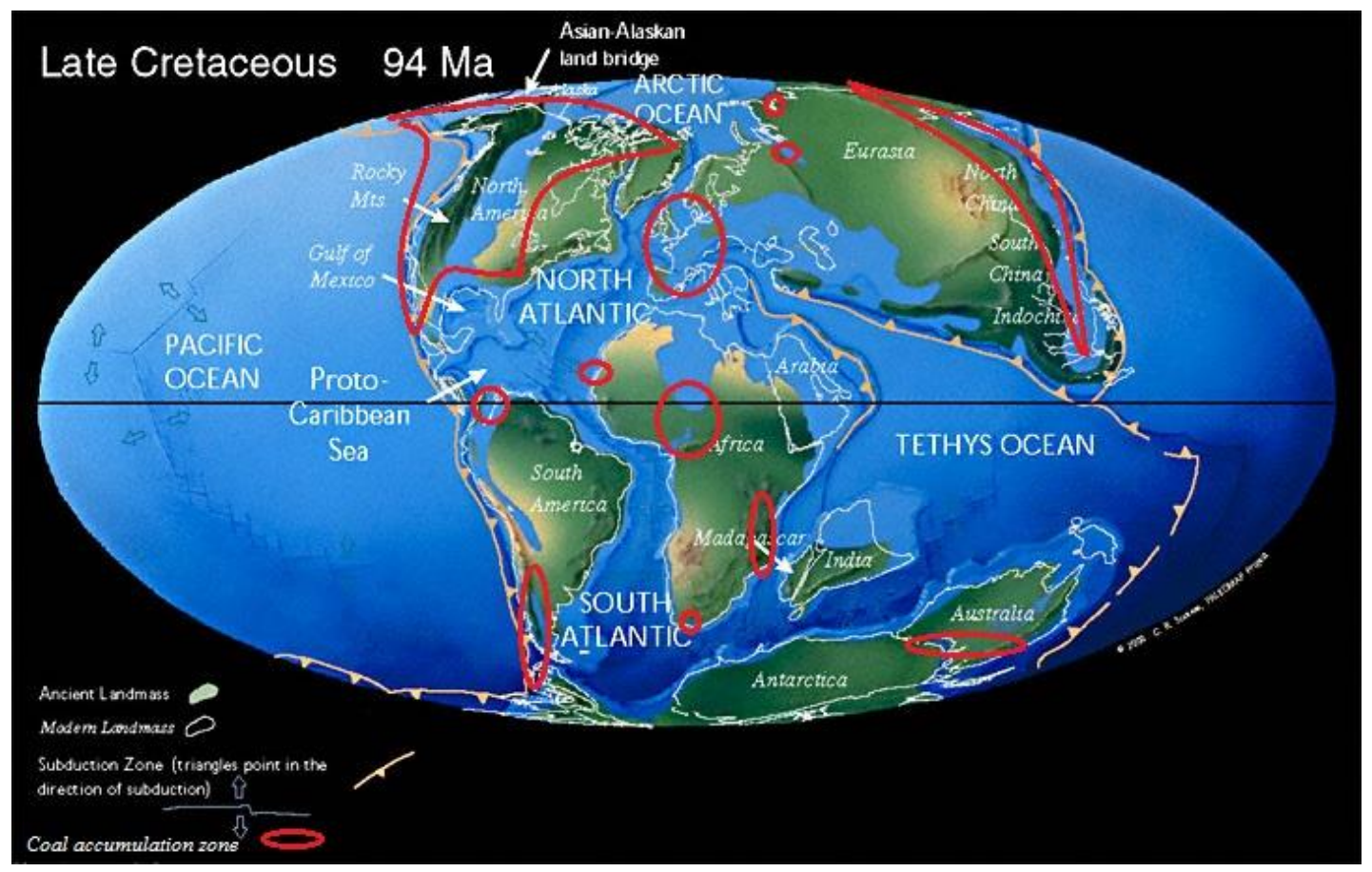

Рис. 6. Зони вугленакопичення в крейді. Виконав автор на основі Paleogeography, PALEOMAP [12, 13] 


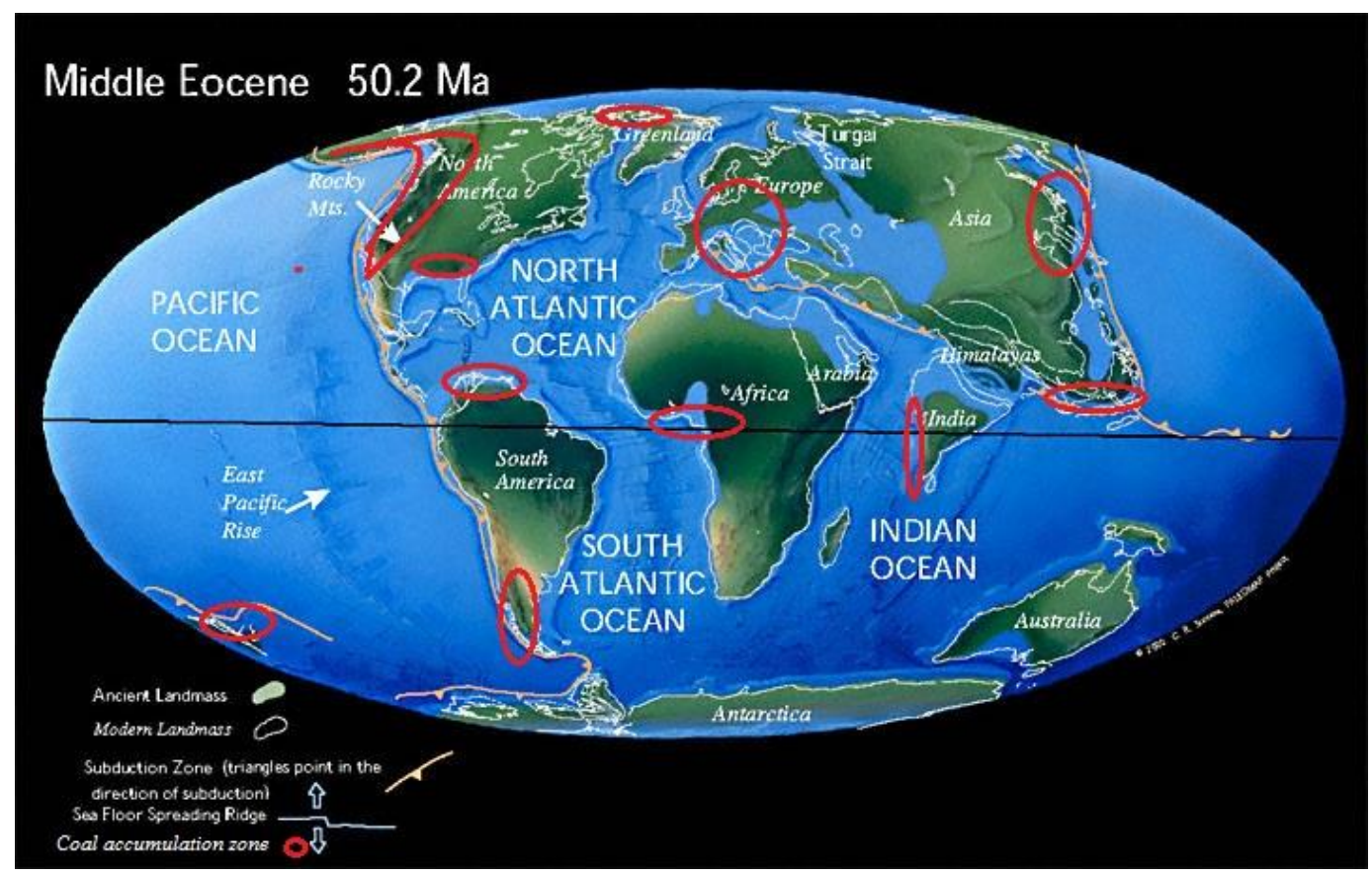

Рис. 7. Зони вугленакопичення в еоцені. Виконав автор на основі Paleogeography, PALEOMAP [12, 13]

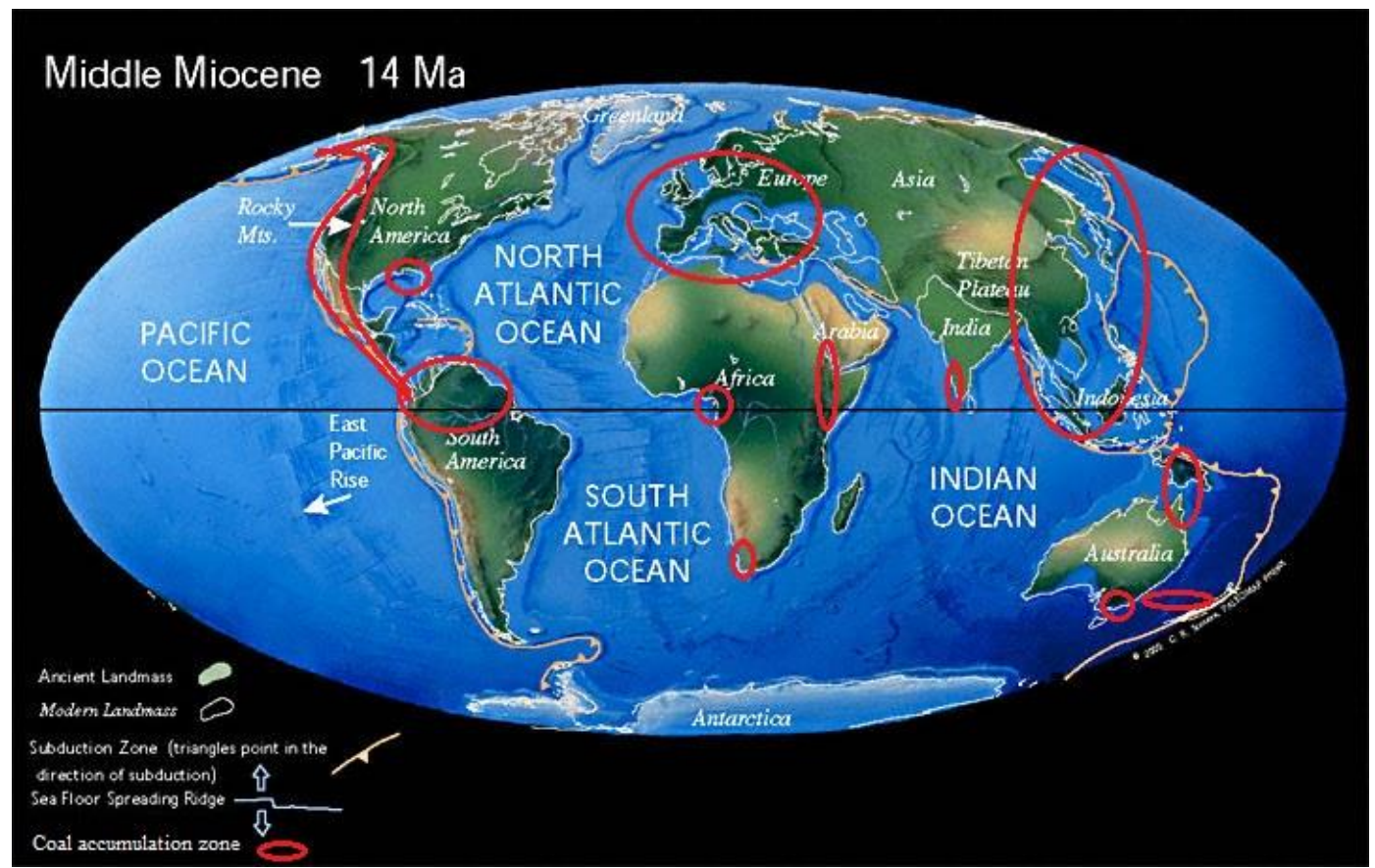

Рис. 8. Зони вугленакопичення в міоцені. Виконав автор на основі Paleogeography, PALEOMAP [12, 13] 


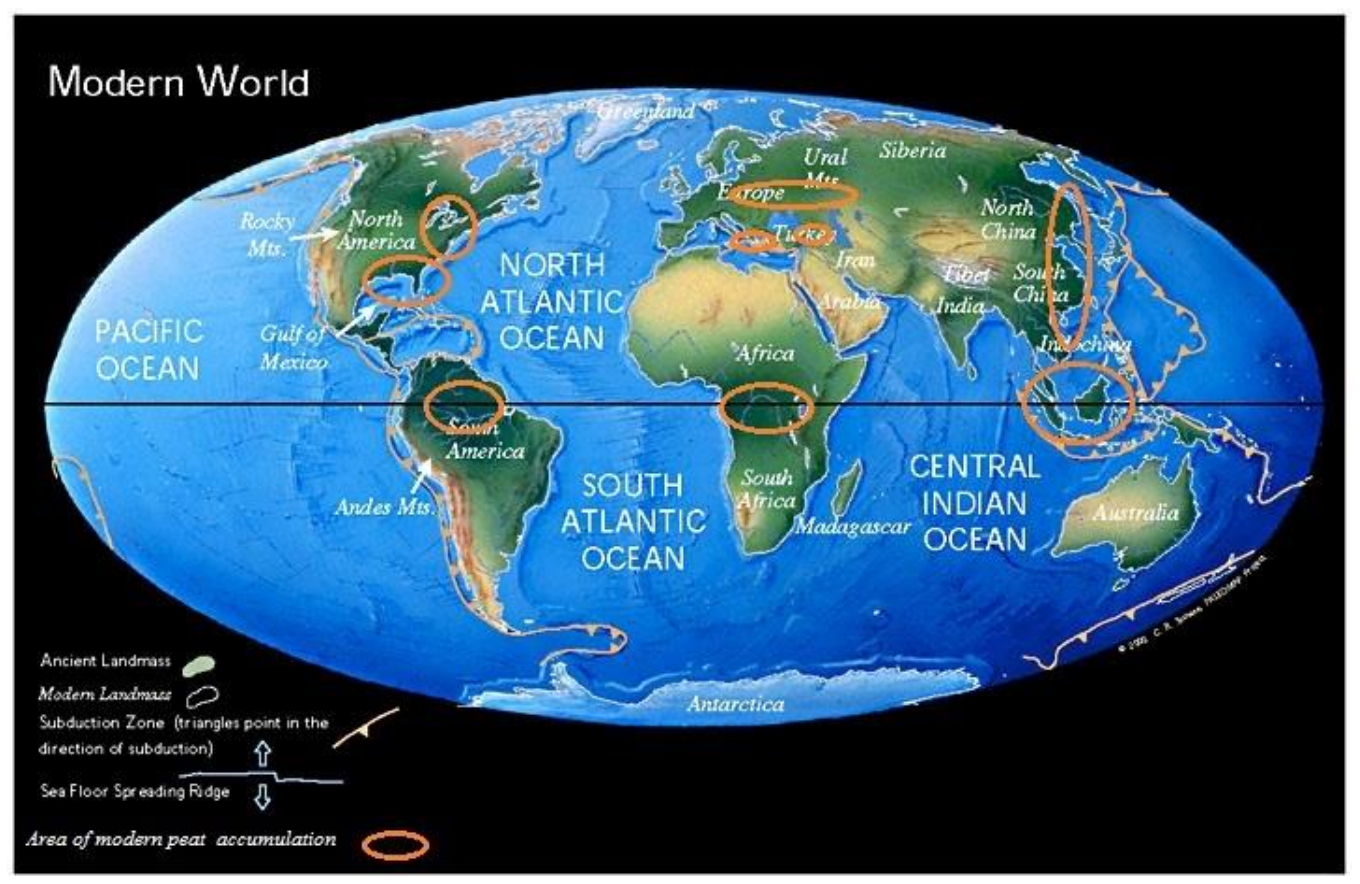

Рис. 9. Зони сучасного торфонакопичення. Виконав автор на основі Paleogeography, PALEOMAP [12, 13]

Промислове (ресурсне) значення різнотипових у геодинамічному відношенні вуглегазоносних басейнів можна оцінити лише наближено, оскільки ціла низка великих поліформаційних басейнів розвивалася в кількох сполучених у просторі й часі геодинамічних ситуаціях, що набували нових характеристик у наступних геодинамічних обстановках та нових ознак з повною чи частковою втратою раніше отриманих.

Докладніші геодинамічні дослідження, які мали безпосередній зв'язок з вугільними й вуглегазовими геологорозвідувальними та регіональними геологічними роботами, проводилися в Донецькому басейні.

Висновок. На основі мобілістської теорії розглянуто можливі реконструкції й за допомогою них упорядковано просторове положення синхронних вугільно-вуглеводневих формацій, які фрормувалися в типових геодинамічних обстановках, закономірно пов'язаних одна з одною в системі давніх плит. Саме в поєднанні інтерпретацій вертикальних формаційних рядів окремих геоструктурних зон з позицій геосинклінально-орогенічного циклу і перехід до переважного латерального геологічних комплексів, розвинених на великих територіях, і полягає особливість геодинамічного аспекту утворення вугільновуглеводневих формацій.

Геодинамічні обстановки, за аналогією із сучасними структурно-тектонічними новоутвореннями, виникають у земній корі внаслідок її реакції на характер глибинного теплоперенесення (геотермодинамічний режим) і відрізняються на різних межах плит і в різних зонах внутрішнього простору материків. Природно, що під час розгляду геодинамічних обстановок формування вуглегазоносних осадових басейнів насамперед цікавили режими розвитку континентальних частин літосферних плит.

Треба зазначити, що система закладених у теорію принципів з базовою моделлю тектоніки плит і сучасними підходами до проведення регіональних геологічних досліджень дає змогу залучати для вирішення завдань вугільної (вуглегазової) геології широкий спектр систематизованої регіональної інформації, яку раніше не використовували і, навпаки, застосовувати дані про вугленосні (вуглегазоносні) відклади для палеогеодинамічних реконструкцій. Особливість розвитку тектоноакумулятивних структур зумовила різноманітність вугільно-вуглеводневих формацій і закономірностей їхнього 
просторово-вікового розміщення та перерозподілу вуглеводневого складника в земній корі. Геодинамічні обстановки торфонакопичення й вуглеутворення - характерні комплекси корових і поверхневих умов (процесів), пов'язаних з їхнім положенням у межах літосферних плит. Як і сучасні, геодинамічні обстановки минулих епох вирізнялися специфікою структуроутворювальних, магматичних і метаморфічних процесів, які, відбиваючись у рельєфі місцевості, створювали особливий вигляд ландшафтнофаціальних умов седиментації. Первинна геодинамічна обстановка фріксувалася в сингенетичних, а наступні - в епігенетичних ознаках вугільно-вуглеводневих формацій, сучасний характер яких ссрормувався внаслідок дискретної зміни геодинамічних обстановок вуглеутворення, що мають на сьогодні кінцевий набір типових різновидів.

\section{СПИСОК ЛІТЕРАТУРИ}

1. Бондарь А.Д., Томчук Ю.Я. Диффференциация изитопов углерода - ключ к решению проблемы генезиса горючих ископаемых. Харьков: ТО Эксклюзив, 2002. 97 с.

2. Егоров А.И. Угленосные и горючесланцевые формации Европейской части СССР. Ростов-на-Дону: Издво Ростовского университета, 1985. 192 с.

3. Иванов Г.А. Угленосные формации. Ленинград: Наука, 1967. 407 с.

4. Матвеев А.К. Угольные бассейны и месторождения зарубежных стран. М.: Изд-во МГУ, 1979. 311 с.

5. Мейен С.В. Из истории растительных династий. М.: Наука, 1971. 224 с.

6. Основные закономерности строения и образования угленосных формаций и методы прогноза угленосности / Под ред. Г.А. Иванова, Н.В. Иванова, А.М. Македонова. Ленинград: Недра, 1985. 255 с.

7. Петрография углей СССР. Основы петрографии углей и методы углепетрографических исследований / Под ред. И.Б. Волковой и И.Э. Вальц. Ленинград: Недра, 1982. 191 с.

8. Табатадзе Д.М. Критические критерии угле- и нефтегазообразования. Тбилиси, 1982. 167 с.

9. Тараканов О.С. Геодинамический анализ угленосных формаций. Санк-Петербург, 1992. Авторесрерат на соиск. уч. степени доктора геол.-мин. наук. 46 с.

10. Тараканов О.С., Романовский С.И., Берг В.И. Литогеодинамический анализ угленосных и турбидитовых формаций. Ленинград: Недра, 1990. 116 с.

11. Угольные бассейны и месторождения стран - членов СЭВ и СФРЮ / ОтВ. ред. Я. Крупа. Москва, 1984. $506 \mathrm{c}$.

12. Scotese C.R. Atlas of Earth History // Paleogeography, PALEOMAP Project, Arlington, Texas, 2001. Vol. 1. 52 p.

13. Scotese C.R. PALEOMAP Project // 2002. http://www.scotese.com, (PALEOMAP website).

\section{REFERENCES}

1. Bondar A.D., Tomchuk Yu.Ya. 2002. The differentiation of carbon isotopes is the key to solving the problem of genesis of fossil fuels. TO Exclusive, Kharkiv, 97 p. - in Russian

2. Egorov A.I. 1985. Coal and combustible shales formations of the European part of the USSR. Rostov University, Rostov-on-Don, 192 p. - in Russian

3. Ivanov G.A. 1967. Coal formations. Science, Leningrad, 407 p. - in Russian

4. Matveev A.K. 1979. Coal basins and deposits of foreign countries. Publishing House of Moscow State University, Moscow, 311 p. - in Russian

5. Meyen S.V. 1971. From the history of plant dynasties. Nauka, Moscow, 224 p. - in Russian

6. Principal regularities of the structure and formation of carbonaceous formations and methods of prediction of fusion / Ed. G.A. Ivanova, N.V. Ivanova, A.M. Makedonova. 1985. Nedra, Leningrad, 255 p. - in Russian

7. Petrography of the Coal of the USSR. Fundamentals of Petrography of Coals and Methods of Coalpetroographic Research / Ed. I.B. Volkova and I.E. Waltz. 1982. Nedra, Leningrad, 191 p. - in Russian

8. Tabatadze D.M. 1982. Critical criteria for coal and oil and gas formation. Tbilisi, 167 p. - in Russian

9. Tarakanov O.S. 1992. Geodynamic analysis of coal-bearing forms. Saint-Petersburg, Abstract on the application. uch. degree doctor geol.-min. sciences, 46 p. - in Russian

10. Tarakanov O.S., Romanovskiy S.I., Berg V.I. 1990. Lithogeodynamic analysis of coal-bearing and turbidite formations. Nedra, Leningrad, 116 p. - in Russian

11. Coal basins and deposits of the countries - members of the CMEA and the SFRY / Ed. Y. Krupa. Moscow, 1984. 506 p. - in Russian 
12. Scotese C.R. Atlas of Earth History. Paleogeography, PALEOMAP Project, Arlington, Texas, 2001. Vol. 1. 52 p.

13. Scotese C.R. PALEOMAP Project. 2002. http://www.scotese.com, (PALEOMAP website).

\section{N.V. Vergelska \\ GEODYNAMIC ASPECTS OF COAL-HYDROCARBONS FORMATIONS}

The sedimentation is only indirectly related to the geodynamic processes generated by the lateral interaction of the lithospheric plates and their displacement, and methods of sedimentary geology objectively tend to represent the primacy of the vertical component of tectonic movements. The urgency of special efforts to solve the problem of coalhydrocarbon formations is due to a number of reasons. First, the most expressive in the doctrine of carbonaceous formations and their connection with the geosynclinal basis already violates the relations with other sections of geology, which are rapidly modernizing, and hinders the further development of the theory of coal gas formation, as part of a single process of evolution by the Pharrose of the lithosphere. Second, the industrial significance of coalhydrocarbon formations, which are associated with the resources of the natural energy carrier, valuable technological raw materials, as well as the complex of related coal and hydrocarbons, metallic and non-metallic minerals, requires the prompt involvement of geodynamic analysis in solving the practical problems of coal geology. On the basis of the mobilist theory - tectonics of plates - considered possible reconstruction and with the help of the ordered spatial position synchronous geological complexes, which were formed in typical geodynamic conditions, naturally associated with each other in the system of ancient plates. In combination of the interpretations of the vertical formation series of individual geostructural zones from the positions of the geosynclinal-orogenic cycle and the transition to the predominant lateral geological complexes, developed on large territories, and the peculiarity of the geodynamic aspect of coal-hydrocarbon formations.

Key words: geodynamics, coal basins, coal-hydrocarbon formations, tectonics, accumulation of organogenic matter.

\section{Н.В. Вергельская \\ ГЕОДИНАМИЧЕСКИЕ АСПЕКТЫ УГОЛЬНО-УГЛЕВОДОРОДНЫХ ФОРМАЦИЙ}

Осадконакопления лишь посредственно связаны с геодинамическими процессами, генерируемыми латеральным взаимодействием литосферных плит и их перемещением, а методы осадочной геологии объективно тяготеют к представлениям о первоочередности вертикальной компоненты тектонических движений. Актуальность особых усилий по решению проблемы угольно-углеводородных формаций обусловлена рядом причин. Во-первых, наиболее выразительная в учении об угленосных формациях и их связи с геосинклинальной основой уже нарушает взаимоотношения с другими разделами геологии, которые быстро модернизируются, и тормозит дальнейшее развитие теории углегазообразования как части единого процесса эволюции фанерозоя литосферы. Во-вторых, промышленное значение угольно-углеводородных формаций, с которыми связаны ресурсы природного энергоносителя, ценного технологического сырья, а также комплекс сопутствующих углю и углеводородам, металлических и нерудных полезных ископаемых, требует скорейшего привлечения геодинамического анализа к решению практических задач угольной геологии. На основе мобилистской теории - тектоники плит - рассмотрены возможные реконструкции и с их помощью упорядочено пространственное положение синхронных геологических комплексов, которые формировались в типичных геодинамических обстановках, закономерно связанных друг с другом в системе древних плит. В сочетании интерпретаций вертикальных формационных рядов отдельных геоструктурных зон С позиций геосинклинально-орогенного цикла и переход к преимущественному латеральному, геологических комплексов, развитых на обширных территориях, и заключается особенность геодинамического аспекта угольно-углеводородных формаций.

Ключевые слова: геодинамика, угольные бассейны, угольно-углеводородные формации, тектоника, накопления органогенного вещества.

Вергельська Наталія Вікторівна

Інститут геологічних наук НАН України

vnata09@meta.ua

Стаття надійшла: 27.09.2017 